\title{
PENYULUHAN HUKUM TENTANG UPAYA MEMINIMALISIR PENIPUAN DALAM BIDANG INVESTASI DI MASYARAKAT DESA SIGERONGAN KABUPATEN LOMBOK BARAT
}

\section{Legal Counseling Education On Efforts To Minimize Fraud In The Field Of Investment In Sigerongan Village Community, West Lombok District}

\author{
I Gusti Agung Wisudawan, Muhammad Sood, Moh. Saleh, Diman Ade Mulada
}

Program Studi Ilmu Hukum Universitas Mataram

Jalan Majapahit Nomor 62, Kota Mataram, Nusa Tenggara Barat. 83115

*Alamat korespondensi : agung.wisudawan@gmail.com

(Tanggal Submission: 27 November 2020, Tanggal Accepted : 5 April 2021)

\begin{abstract}
Keyword : Abstract :
Investasi, Kegiatan investasi di Indonesia mengalami pertumbuhan yang sangat pesat dari Penipuan tahun ke tahun, investasi yang dikenal saat ini bukan hanya di sektor perbankan saja tetapi lembaga keuangan non bank. Tetapi ada hal yang perlu diperhatikan ketika berinvestasi adalah harus berhati-hati dengan adanya penipuan dalam bidang investasi apalagi investasi secara on line, hal ini terjadi seiring dengan pesatnya aplikasi di era digitalisasi dan revolusi industri 4.0 saat ini. Kegiatan pengabdian kepada masyarakat ini bertujuan untuk meminimalisir penipuan dalam bidang investasi di masyarakat bertujuan untuk meningkatkan pemahaman dan kesadaran masyarakat khususnya di Desa Sigerongan, Kecamatan Lingsar, Kabupaten Lombok Barat sehingga masyarakat desa akan terhindar dari kerugian yang disebabkan oleh penipuan dalam bidang investasi. Hasil kegiatan pengabdian kepada masyarakat ini adalah masyarakat Desa Sigerongan merasa sangat terbantu dengan adanya informasi tentang berbagai jenis penipuan dalam bidang investasi dan modus operandinya, selain itu masyarakat juga dapat mengetahui upaya yang dilakukan agar terhindar dari praktik penipuan investasi.
\end{abstract}

Panduan sitasi / Citation guidance (APPA $7^{\text {th }}$ edition) :

Wisudawan, I. G. A., Sood, M., Saleh, M., \& Mulada, D. A. (2021). Penyuluhan Hukum Tentang Upaya Meminimalisir Penipuan Dalam Bidang Investasi Di Masyarakat Desa Sigerongan Kabupaten Lombok Barat. Jurnal Abdi Insani Universitas Mataram, 8 (1), 126-133. http://doi.org/10.29303/abdiinsani.v8i1.365

\section{PENDAHULUAN}

Kegiatan investasi di Indonesia mengalami pertumbuhan yang sangat pesat dari tahun ke tahun, investasi yang dikenal saat ini bukan hanya di sektor perbankan saja tetapi lembaga keuangan 
non bank. Investasi merupakan penempatan uang atau dana dengan harapan untuk memperoleh tambahan atau keuntungan tertentu atas uang atau dana tersebut. Pada dasarnya investasi merupakan kegiatan menanamkan modal pada suatu perusahaan atau aset dengan nilai yang tinggi dengan tujuan untuk mendapatkan keuntungan yang berlipat-lipat di kemudian hari. Jadi ekspektasi dari kegiatan investasi yang dilakukan oleh masyarakat sudah pasti adalah keuntungan, tentu keuntungan yang didapatkan tersebut melalui bisnis investasi yang legal.

Alternatif dalam kegiatan investasi memang beragam seperti deposito di perbankan, emas, bursa efek, bursa uang, bursa komoditi, koperasi, properti dan masih banyak lagi. Tetapi ada hal yang perlu diperhatikan ketika berinvestasi adalah harus berhati-hati dengan adanya penipuan dalam bidang investasi apalagi investasi secara on line, hal ini terjadi seiring dengan pesatnya aplikasi di era digitalisasi dan revolusi industri 4.0 saat ini. Tercatat ada beberapa kasus penipuan dalam bidang investasi yang terjadi di Indonesia, antara lain Kasus penipuan "Teman Berjalan", kedok investasi dengan menggunakan badan usaha, dan investasi penggemukan sapi bodong. Kasus Penipuan "Teman Berjalan" terjadi dengan cara menyebarkan promosi untuk mencari korban secara berantai (Suara NTB, 2020). Dalam hal ini, penipu memasarkan investasi bodongnya dengan nominal uang rupiah yang satu dengan yang lainnya berbeda (Nursalim, 2020). Kedok Investasi dengan Mengatasnamakan Badan Usaha merupakan penipuan yang lebih licik dan cerdas hal ini terjadi karena pelaku penipuan meminjam nama perusahaan lain untuk penipu para korbannya. Investasi Penggemukan Sapi Bodong di Ponorogo. Kedua tersangka adalah Hadi Suwito sebagai pemilik CV Tri Manunggal Jaya (TMJ) dan bendahara Arie Setiawan yang menawarkan investasi fiktif.Adapun modus para tersangka menawarkan kepada masyarakat secara door to door investasi penggemukan sapi perah dengan sistem paket yang telah ditentukan harganya lengkap dengan keuntungannya tetapi pada akhirnya keuntungan itu tidak diberikan oleh pelaku penipuan.

Satuan Tugas (Satgas) Waspada Investasi Otoritas Jasa Keuangan mengimbau kepada masyarakat untuk berhati-hati terhadap 72 entitas yang diduga melakukan penipuan dengan modus investasi atau kegiatan usaha tanpa izin dan berpotensi merugikan masyarakat, menurut penuturan Tongam, kasus investasi yang ditemukan rata-rata bukan terkait sektor jasa keuangan, tapi kebanyakan berupa kasus penipulan multilevel marketing (MLM), crypto currency, dan kasus-kasus investasi ilegal. Berbagai kasus yang telah Penyusun uraikan di atas sudah tentu akan merugikan masyarakat sekaligus membuat kersahan pada masyarakat itu sendiri. Oleh karena itu diperlukan ketegasan dan peran aktif dari aparat keamanan seperti polisi ataupun Satgas Waspada Investasi yang dibentuk oleh Otoritas Jasa Keuangan (OJK) dalam mengungkap kasus-kasus penipuan investasi (Protomo, 2020).

Sigerongan merupakan salah satu desa yang ada di kecamatan Lingsar, Kabupaten Lombok Barat, provinsi Nusa Tenggara Barat, Indonesia. Desa merupakan satu dari 10 desa dan kelurahan yang berada di kecamatan Lingsar. Desa ini memiliki kodepos 83371. Adapun Dusun yang terdapat di Desa Sigerongan adalah sebagai berikut Dusun Sigerongan,Dusun Embung Pas Barat,Dusun Embung Pas Timur,Dusun Berembung Barat,Dusun Repok Pancor dan Dusun Jati Mekar. Adapun yang menjadi tujuan dan manfaat kegiatan pengabdian masyarakat yang dilakukan yaitu untuk meningkatkan pemahaman dan kesadaran masyarakat sehingga terhindar dari kerugian yang disebabkan oleh penipuan dalam bidang investasi mengingat akitivitas masyarakat yang sangat beragam dan rentan dengan penipuan investasi, Sasaran pengabdian kepada masyarakat adalah masyarakat Desa Sigerongan, Kecamatan Lingsar, Kabupaten Lombok Barat, kegiatan pengabdian ini juga diharapkan mampu memberikan informasi yang berharga bagi masyarakat tentang jenis-jenis dan modus operasi 
investasi bodang yang telah terjadi sehingga masyarakat tidak terjebak lagi dengan hal yang serupa di masa yang akan datang.

\section{METODE KEGIATAN}

Kegiatan Pengabdian kepada Masyarakat ini dilakukan melalui penyuluhan hukum langsung ke masyarakat. Kegiatan penyuluhan hukum ini dilakukan dengan penyampaian materi dalam bentuk ceramah dan diskusi, tentang jenis-jenis penipuan dalam bidang investasi, upaya untuk menghindarkan diri dari penipuan investasi, cara pelaporan dan sanksi hukum bagi penipuan dalam bidang investasi. Nara sumber adalah Tim Pengabdian Masyarakat dan berkoordinasi dengan aparat Desa Sigerongan, Kecamatan Lingsar Kabupaten Lombok Barat. Evaluasi dapat dilaksanakan sebelum, selama dan sesudah kegiatan selesai dilaksanakan, yang dinyatakan dengan metode komparasi. Metode ini dilakukan dengan analisis secara kualitatif. Tolak ukurnya antara lain meliputi perbandingan kehadiran undangan, keseriusan dalam megikuti kegiatan, kemudian daya serap dilihat dari cara mengemukakan pertanyaan-pertanyaan/pendapat keaktifan dan alternatif penyelesaian masalah

\section{HASIL DAN PEMBAHASAN}

\section{Upaya meminimalisir terjadinya penipuan dalam bidang investasi pada masyarakat desa sigerongan, kecamatan lingsar, kabupaten lombok barat.}

Indonesia saat ini sedang memasuki era perdagangan bebas dan era globalisasi, masyarakat Indonesia memiliki mindset untuk berinvetasi di berbagai bidang dengan harapan untuk memperoleh keuantungan yang sebesar-besarnya. Saat ini semua harga kebutuhan hidup dan gaya hidup semakin meningkat dengan drastis sehingga diperlukan berbagai cara untuk bisa memenuhi kebutuhan ini. Terkadang tabungan atau deposito menjadi pilihan utama dalam menghadapi hari tua maupun juga sebagai persiapan keperluan di masa depan nanti seperti pendidikan. Selanjutnya kegiatan investasi bisa berkembang dan menjadi berlipat meskipun membutuhkan waktu yang tidak sedikit. Hanya saja maraknya penipuan saat ini dengan dengan modus investasi semakin marak dan dapat merugiakan masyarakat pada umumnya. Untuk itu perlu dipahami tentang ciri-ciri dari investasi bodong (penipuan investasi) sehingga bisa terhindar dari penipuan dan upaya yang dilakukan untuk meminimalisir terjadinya kerugian dari praktik penipuan investasi (CNN Indonesia, 2018).

Investasi merupakan upaya penanaman modal untuk mendapatkan keuntungan di kemudian hari. Modal bisa berupa uang atau sumber daya yang lain. Dengan berinvestasi, orang berharap bisa mendapatkan manfaat di masa mendatang. Oleh karena itu dalam berinvestasi diharapkan masyarakat lebih berhati-hati dalam menempatkan dananya. Seiring dengan pesatnya penggunaan internet sebagai sarana komunikasi, maka praktik penipuan dalam bidang investasi ini juga semakin canggih. Kasus yang dapat diketahui hari ini yaitu penipuan melalui pinjaman online atau Fintech, yang dalam hal ini Fintech yang dimaksud tidak memperoleh izin dari Otoritas Jasa Keuangan. Ada juga kasus terkait dengan investasi dengan menyerahkan sejumlah uang yang kemudian uang itu akan dibungakan melebihi suku bunga Bank Indonesia dan dijanjikan bahwa investor akan mendapat keuntungan berlipat setiap harinya, ketika pembayaran bunga itu macet maka investor akan menderita kerugian yang besar.

Keadaan ini tentunya tidak bisa dibiarkan begitu saja yang tertipu dari praktik investasi ini bukan hanya masyarakat di perkotaan tetapi yang juga sangat rentan terken dampaknya adalah warga desa. Oleh karena itu penulis tergerak untuk mengadakan kegiatan pengabdian kemitraan dalam bentuk penyuluhan hukum ke salah satu Desa yaitu Desa Sigerongan, Kecamatan Lingsar, Kabupaten Lombok Barat, paling tidak masyarakat akan mendapatkan informasi yang komperhensif tentang 
jenis-jenis penipuan investasi dan upaya untuk menghindarkan diri dari praktik penipuan investasi tersebut.

Peranan hukum dalam pembangunan ekonomi Indonesia salah satunya adalah menciptakan stabilitas atau keadaan yang aman dan nyaman. Keadaan ini memang sangat dibutuhkan dalam hubungannya dengan kegiatan investasi, oleh karena itu diperlukan pengaturan mengenai kegiatan investasi dalam bentuk Hukum Investasi. Menurut Salim \& Sutrisno (2008), menyatakan bahwa "Hukum Investasi adalah keseluruhan kaidah hukum yang mengatur hubungan antara investor dengan penerima modal, bidang-bidang usaha yang terbuka untuk investasi, serta mengatur tentang prosedur dan syarat-syarat dalam melakukan investasi dalam suatu negara". Titik tekan yang paling utama dalam kegiatan investasi adalah terbinanya salaing pengertian antara investor dengan penerima modal, jika ada yang disembunyikan atau ditutup tutupi dalam kegiatan investasi tentunya akan berdampak pada kerugian investor (Ferdiani, 2019). Artinya dalam kegiatan investasi bukan hanya berbicara tentang kepastian saja atau kemanfaatan secara pragmatis saja tetapi juga berbicara tentang keadilan. Setiawan (2021) menyatakan bahwa keadilan dimaknai "sebagai hal-hal yang berkenaan pada suatu sikap dan juga tindakan didalam hubungan antar manusia yang berisi tentang sebuah tuntutan agar sesamanya dapat memperlakukan sesuai hak dan juga sesuai kewajibannya". Jadi dalam hal ini yang harus diperhatikan adalah kepentingan investor.

Berikut ini adalah ciri-ciri dari investasi bodong atau investasi palsu yaitu :

1. Menjanjikan imbal hasil tinggi dalam waktu singkat dengan minim risiko

Setiap investasi pasti memiliki risiko. Semakin tinggi jumlah yang Sobat investasikan maka semakin tinggi pula risikonya. Jika Sobat mendapat penawaran investasi yang menjanjikan imbal hasil tinggi, namun dengan iming-iming minim risiko atau bahkan tidak ada sama sekali. Maka harus mencurigai kegiatan atau produk investasi ini. Pada kegiatan atau produk investasi yang legal, Sobat pasti akan mendapatkan penjelasan mengenai risiko-risiko yang bisa saja menimpamu.

2. Legalitas tidak tercantum di Otoritas Jasa Keuangan (OJK)

Perusahaan investasi harus mendaftarkan diri dan menunggu izin operasi terlebih dahulu dari berbagai pihak seperti OJK, setelahnya barulah perusahaan investasi bisa menjalankan bisnisnya.Ketika menanyakan surat izin namun surat izin dari belum lengkap atau bahkan tidak bisa menunjukkan, Sobat patut untuk mencurigai legalitas perusahaan investasi tersebut.

3. Memanfaatkan nama tokoh masyarakat

Untuk meyakinkan calon korbannya, biasanya investasi bodong akan mencatut nama orang terkenal mulai dari selebriti hingga tokoh masyarakat. Padahal, sebagian besar tokoh-tokoh yang dicatut namanya ini tidak pernah mengenal perusahaan investasi tersebut. Untuk memastikan, Sobat bisa mengecek di sosial media selebriti atau tokoh masyarakat yang dicatut namanya. Karena jika memang mereka mendapatkan keuntungan dari investasi tersebut, biasanya mereka secara sukarela akan menceritakan pengalamannya kepada para pengikut sosial medianya.

4. Meminta bergabung dengan cara mendesak

Dalam mengajak calon nasabahnya, pelaku investasi bodong akan meminta dan mendesak Sobat untuk segera bergabung, dengan iming-iming prospek keuntungan yang menggiurkan atau keuntungan berlipat ganda. Beberapa contoh ajakan yang mendesak seperti "Segera gabung dengan kami untuk meraih keuntungan yang berlipat dan cepat".

5. Informasi yang disajikan sangat terbatas

Pada umumnya, investasi yang legal akan menjelaskan sejelas-jelasnya pada calon investor tentang model investasi dan pengelolaan dananya. Namun, hal sebaliknya akan Sobat temukan 
pada investasi bodong. Kantrimaharani (2016) menyatakan bahwa, bahkan saat korban meminta penjelasan mengenai model pengelolaan dana dan ke mana aset dialokasikan, pelaku investasi bodong akan memberikan jawaban yang berputar-putar, tidak gamblang bahkan cenderung menghindari pertanyaan seperti ini.

6. Rekam jejak yang fiktif

Investasi bodong akan mengklaim keberhasilannya secara sepihak dan tidak dapat dipertanggungjawabkan. Misalnya, mengklaim memiliki banyak rekam jejak kepuasan investor tetap, pengalaman bertahun-tahun dalam dunia investasi bahkan hingga menerima penghargaan dan menghasilkan uang dengan jumlah yang fantastis.

Diharapkan dengan informasi ini maka masyarakat desa akan mengetahui secara lengkap dan komperhentif tentang ciri-ciri investasi yang palsu dan bodong agar dapat berhati-hati dalam menempatkan dananya untuk berinvestasi. Penulis juga menjelaskan tentang kasus terbaru penipuan investasi yang terjadi di NTB salah satunya yaitu Seorang perempuan berinisial LC alias Emak Caca (28) ditahan dan ditetapkan sebagai tersangka oleh Polresta Mataram. Wanita yang bekerja sebagai chef tersebut diduga menjadi pelaku penipuan berkedok investasi rumah makan yang dikelolanya sendiri. LC merupakan owner Dapur Emak, yang berlokasi di Kota Mataram. Polisi menyebut terbongkarnya kasus ini setelah dilaporkan oleh seseorang yang menjadi korban penipuan Emak Caca. Kadek menyebut korban awalnya berinvestasi sebesar Rp 25 juta dan dijanjikan akan mendapatkan keuntungan lebih besar hingga Rp 36 juta dalam waktu 3 bulan. Perjanjiannya, pelaku akan memberi keuntungan dan pengembalian pokok sebesar Rp 400 ribu setiap hari kerja. Yakni dari hari Senin sampai Jumat selama 90 hari. Korban tergiur dan dengan keuntungan bersih beserta modal sebesar Rp 36 juta. Keuntungan tersebut hanya janji dari pelaku. Tapi sampai sekarang belum ada kejelasan keuntungan itu sama sekali belum didapat. Sejak pelaku dilaporkan, polisi kemudian menangkap Emak Caca dan langsung ditahan. Sejak saat itu, sejumlah netizen pun mengaku menjadi korban dengan total investasi yang mencapai ratusan juta rupiah. Namun hingga kini, baru satu orang korban yang melapor ke polisi. Selain itu ada beberapa kasus investasi palsu yaitu ermasuk arisan online, periklanan, multi level marketing, dan kegiatan berkedok koperasi. Sepanjang ada kegiatan yang menyangkut uang dan merugikan masyarakat dan didefinisikan sebagai investasi ilegal.

Perkembangan terbaru menurut Kepala Departemen Penyidikan Sektor Jasa Keuangan Otoritas Jasa Keuangan (OJK) dan Ketua Satgas Waspada Investasi (SWI) Tongam L. Tobing mengatakan perkembangan investasi ilegal yang ditangani oleh SWI semakin meningkat dari tahun ke tahun. Pada 2017, ada 79 entitas investasi ilegal. Tahun berikutnya, entitas investasi ilegal yang ditangani bertambah menjadi 106 dan masuk fintech lending ilegal atau pinjaman daring ilegal sebanyak 404. Pada 2019, SWI menangani sekitar 442 entitas investasi ilegal, Tahun ini, sampai dengan September 2020, ada 195 entitas investasi ilegal yang dihentikan oleh SWI disamping pegadaian ilegal dan fintech lending ilegal. hal ini menunjukkan peningkatan kasus yang sangat signifikan sehingga diperlukan komitmen bersama antara OJK, Satgas Waspada Investasi dan masyarakat dalam rangka pengungkapan kasus dan penegakan hukum terhadap investasi palsu yang meresahkan masyarakat ini.

Kesadaran hukum dan pemahaman hukum kepada masyarakat menjadi hal yang sangat penting. Hukum investasi tentu sangat erat kaitannya dengan Hukum Perbankan yang secara tegas mengancam kepada barang siapa yang menghimpun dana dari masyarakat tanpa izin dari lembaga terkait seperti BI dan OJK, sehingga atas perbuatan tersebut dikategorikan sebagai penipuan investasi 
bodong dan dapat diancam dengan pidana penjara serta denda sebagaimana dimaksud di dalam Undang-undang No 10 Tahun 1998 Tentang Perubahan Atas Undang-undang No 7 Tahun 1992 Tentang Perbankan, Undang-undang No 21 Tahun 2011 Tentang Otoritas Jasa Keuangan dan KUHP.

Adapun upaya yang dapat dilakukan oleh masyarakat desa yang sangat rentan berhadap dengan investasi bodong atau palsu yaitu :

\section{Cari tahu dahulu informasi secara detail tentang lembaga tersebut}

Langkah pertama yang harus dilakukan calon investor adalah mencari tahu terlebih dahulu informasi lengkap dari lembaga yang menawarkan investasi. Kalau perlu kroscek sampai tuntas mengenai kantor lembaganya, karyawan, dan produknya.

\section{Datang langsung untuk melihat produknya}

Karena hal ini mempertaruhkan uang Anda, jadi Anda wajib datang langsung untuk melihat produknya. Jangan sampai fiktif. Misalnya lembaga tersebut menawarkan investasi hewan Qurban, maka Anda juga harus tahu bagaimana mereka mempersiapkan produknya dan bagaimana pangsa pasarnya, jika perlu, mintalah data salinan tertulis rencana pemasaran dan penjualan dari perusahaan.

\section{Lihatlah risiko secara utuh.}

Alangkah baiknya bila Anda menganalisis dampak positif dari keuntungan namun juga kemungkinan risiko yang terjadi. Perlu diingat semakin besar keuntungan yang diiming-imingi, semakin besar risiko kerugian yang akan Anda alami bukan

Berdasarkan hal tersebut di atas maka telah jelas bahwa masyarakat harus terus berhatihati dan mencermati berbagai kegiatan investasi saat ini agar tehindar dari jerat investasi palsu yang merugikan. Peran dari Satgas Waspada Investasi sangat diperlukan dalam rangka melakukan penegakan hukum terhadap kasus-kasus investasi palsu yang meresahkan masyarakat ini. Satgas ini dibentuk Otoritas Jasa Keuangan (OJK) bersama dengan Kementerian Perdagangan, Kementerian Komunikasi dan Informatika, Kemeterian Koperasi dan Usaha Kecil dan Menengah, Kejaksaan, Kepolisian RI, dan Badan Koordinasi Penanaman Modal (BKPM) dalam rangka memperkuat kerjasama untuk mencegah dan menangani maraknya tawaran dan praktek investasi ilegal di tengah-tengah masyarakat. Satgas Waspada Investasi dibentuk melalui Surat Keputusan Ketua Bapepam dan LK Nomor: Kep-208/BL/2007 tanggal 20 Juni 2007 untuk masa kerja tahun 2007 yang diperbarui setiap tahunnya. Setelah beralihnya tugas dan fungsi Bapepam (Badan Pengawas Pasar Modal) dan LK menjadi Otoritas Jasa Keuangan (OJK), Surat Keputusan Satgas Waspada Investasi tersebut diperbarui melalui Keputusan Dewan Komisioner OJK Nomor: 01/KDK.04/2013 tanggal 26 Juni 2013.

Adapun sanksi hukum yang telah menanti para pelaku kejahatan di bidang investasi ini adalah Pasal 378 KUHP yaitu : Barangsiapa dengan maksud untuk menguntungkan diri sendiri atau orang lain secara melawan hukum dengan menggunakan nama palsu atau martabat (hoedaningheid) palsu; dengan tipu muslihat, ataupun rangkaian kebohongan, menggerakkan orang lain untuk menyerahkan barang sesuatu kepadanya, atau supaya memberi utang maupun menghapuskan piutang, diancam, karena penipuan, dengan pidana penjara paling lama empat tahun.

Selain itu investasi yang berkedok sebagai bank maka akan dikenakan sanksi sebagaimana yang dimaksud di dalam Pasal 46 Undang-Undang No. 7 Tahun 1992 jo Undang-Undang No. 10 Tahun 1998 tentang Perbankan yang menyatakan bahwa : Pasal 46 Ayat (1) : "Barang siapa menghimpun dana dari masyarakat dalam bentuk simpanan berupa giro, deposito berjangka, sertifikat deposito, tabungan, dan/atau bentuk lainnya yang dipersamakan dengan itu tanpa izin usaha dari Menteri sebagaimana dimaksud dalam Pasal 16 dan Pasal 17, diancam dengan pidana penjara paling lama 15 
(lima belas) tahun dan denda paling banyak Rp. 10.000.000.000,-(sepuluh miliar rupiah) dan paling banyak Rp. 200.000.000.000,-(duaratus miliar rupiah).

Harapannya dengan sanksi hukum yang telah diuraikan di atas dan adanya Satgas Waspada Investasi ini akan mampu meminimalisir terjadinya praktik investasi palsu di tengah-tengah masyarakat. Adapun yang menjadi hasil kegiatan pengabdian kemitraan ini masyarakat Desa Sigerongan, Kecamatan Lingsar Kabupaten Lombok Barat meningkat kesadaran hukumnya untuk selalu berhati-hati dalam berinvestasi agar terhindar dari investasi bodong atau palsu.

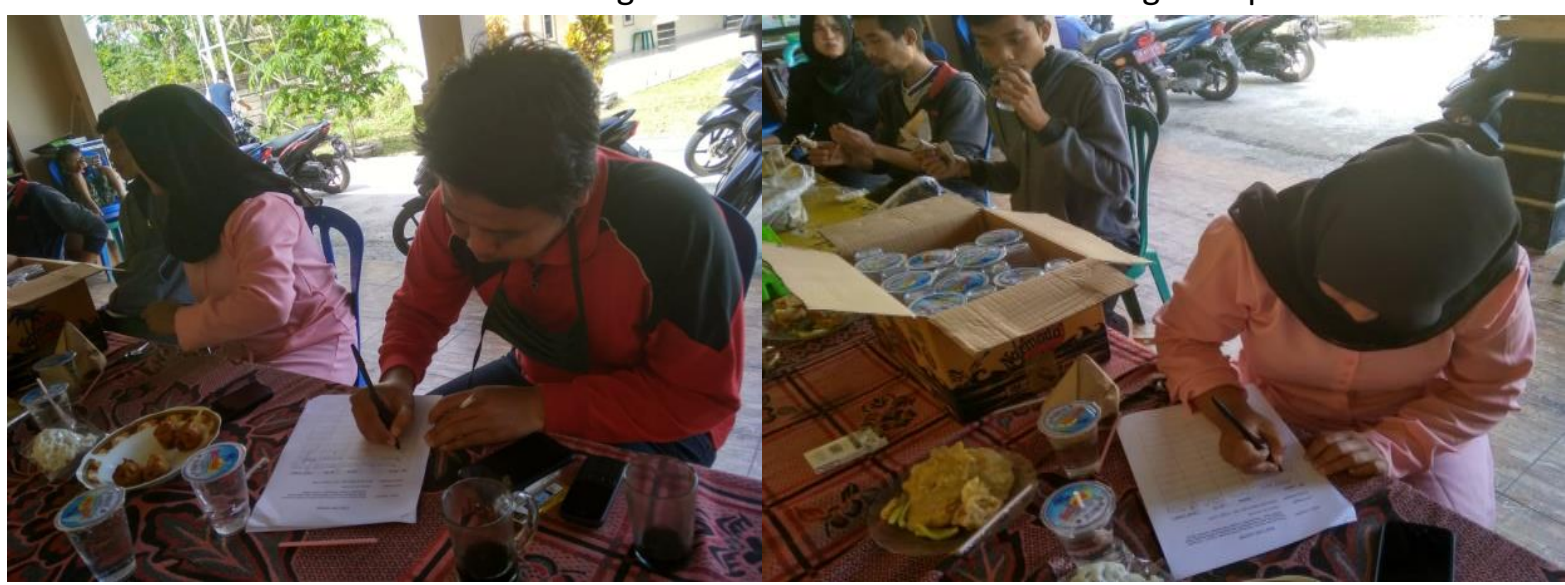

Gambar 1. Suasana Registrasi peserta Kegiatan Pengabdian Masyarakat di Desa Sigerongan

\section{SIMPULAN DAN SARAN}

\section{Simpulan}

Kegiatan pengabdian masyarakat kemitraan dalam bentuk penyuluhan hukum ini sangat penting dilaksanakan kepada masyarakat Desa Sigerongan, Kecamatan Lingsar Kabupaten Lombok Barat sehingga meningkat pemahaman dan kesadaran hukumnya untuk selalu berhati-hati dalam berinvestasi agar terhindar dari investasi bodong atau palsu. Selain itu materi yang disampaikan sangat komperhensif mulai dari jenis-jenis investasi palsu, kasus-kasus hukumnya dan upaya menghindari investasi palsu.

\section{Saran}

Adapun saran yang dapat diberikan adalah kegiatan penyuluhan hukum ini harus dilakukan secara berkala dalam rangka terus memberikan pemahaman dan peningkatan kesadaran hukum kepada masyarakat tentang upaya untuk meminimalisir terjadinya penipuan dalam bidang investasi yang akhir-akhir ini kasusnya semakin meningkat.

\section{UCAPAN TERIMA KASIH}

Kegiatan pengabdian ini dapat berlangsung atas bantuan banyak pihak. Dalam kesempatan ini tim pelaksana menyampaikan ucapan terima kasih kepada Universitas Mataram yang telah memberikan pendanaan kegiatan, Bapak Syahrul Azwar selaku Sekertaris Desa Sigerongan serta masyarakat Desa Sigerongan, Kecamatan Lingsar Kabupaten Lombok Barat yang telah mendukung dan mensukseskan kegiatan ini. 


\section{DAFTAR PUSTAKA}

CNN Indonesia. (2018) OJK ungkap 72 investasi bodong sepanjang januari-april 2018. https://www.cnnindonesia.com/ekonomi/20180420163312-78-292338/ojk-ungkap72-investasi-bodong-sepanjang-januari-april-2018 diakses diakses Pada Hari Senin Tanggal 24 Februari 2020 Jam 11.25 Wita.

Ferdiani, K.R. (2019). Pengertian Investasi, Jenis, dan Manfaatnya. https://www.modalrakyat.id/blog/pengertian-investasi-jenis-dan-manfaatnya diakses pada hari Rabu 18 November 2020 jam 09.50 Wita.

Kantrimaharani. (2016). 6 Cara Menghindari Jerat Investasi Bodong. https://www.liputan6.com/properti/read/2676634/6-cara-menghindari-jeratinvestasi-bodong diakses pada hari Selasa, tanggal 18 November 2020 jam 11.00 Wita

Nando, M. (2017). Kajian Hukum dan Investasi dan Perlindungan Terhadap Korban Investasi Bodong. Lexs 5 https://ejournal.unsrat.ac.id/index.php/administratum/article/view/15138/14701

Nursalim, A. (2020). Mengenal Ciri Investasi Bodong. https://www.akseleran.co.id/blog/mengenalciri-investasi-bodong/ diakses pada hari Selasa, tanggal 18 November 2020 jam 10.32 Wita

Protomo, M. N. (2020). OJK Setop 195 Investasi Bodong, dari Modus MLM Sampai Koperasi https://finansial.bisnis.com/read/20201022/55/1308508/ojk-setop-195-investasibodong-dari-modus-mlm-sampai-koperasi diakses pada hari Selasa, tanggal 18 November 2020 jam 11.00 Wita.

Salim, H.S., \& Sutrisno, B. (2008). Hukum Investasi di Indonesia. Rajawali Pers : Jakarta.

Setiawan, P. (2021). Pengertian Keadilan - Makna , Macam, Landasan, Sosial, Para Ahli https://www.gurupendidikan.co.id/pengertian-keadilan/ diakses pada hari Selasa, tanggal 18 November 2020 jam 10.20 Wita

Suara NTB. (2020). Kasus Investasi Dapoer Emak Caca, Tersangka Berdalih Terdampak Pandemi https://www.suarantb.com/kasus-investasi-dapoer-emak-caca-tersangka-berdalihterdampak-pandemi/ diakses pada hari Selasa, tanggal 18 November 2020 jam 10.32 Wita 